Jurnal Pendidikan dan Pembelajaran Kimia, Vol. 8, No. 2, Tahun 2019.

Program Studi Kimia. FKIP. Universitas Lampung

https://jurnal.fkip.unila.ac.id/

\title{
Efektivitas Model Pembelajaran POGIL untuk Meningkatkan Keterampilan Berpikir Tingkat Tinggi pada Materi Garam Menghidrolisis
}

\author{
Elis*, Ila Rosilawati, Chansyanah Diawati \\ FKIP Universitas Lampung, J1. Prof. Dr. Soemantri Brojonegoro No.1 Bandar Lampung \\ *e-mail: elisnashrullah@gmail.com,Telp : +628989067155
}

Abstract: The Effectiveness of POGIL Learning Model to Improve High Order Thinking Skills on the Hydrolyzing Salt. This research was aimed to describe the effectiveness of Process Oriented Guided Inquiry Learning (POGIL) to improve high order thinking skills (HOTS) on hydrolyzing salt. The method of this research was quasi-experimental with pretest-posttest control group design. The population of this research was all students of XI MIA class at Senior High School in Lampung Selatan. The samples were taken using a purposive sampling technique and obtained XI MIA 1 as the experiment class and XI MIA 4 as a control class. The data analysis used the two average difference test, namely the $t$ test. The result of the research showed that the average n-gain of high order thinking skills applied by the POGIL learning model was higher than the average n-gain of high order thinking skills with a conventional model. There was a significant n-gain difference between the experiment class and the control class. Thus, it was concluded that the POGIL learning model was effective for increasing high order thinking skills on hydrolyzing salt.

Keywords : high order thinking skill, hydrolyzing salt, POGIL.

\begin{abstract}
Abstrak: Efektivitas Model Pembelajaran POGIL untuk Meningkatkan Keterampilan Berpikir Tingkat Tinggi pada Materi Garam Menghidrolisis. Penelitian ini bertujuan untuk mendeskripsikan efektivitas model pembelajaran Process Oriented Guided Inquiry Learning (POGIL) untuk meningkatkan keterampilan berpikir tingkat tinggi pada materi garam menghidrolisis. Metode penelitian yang digunakan adalah kuasi eksperimen dengan pretest-postest control group design. Populasi penelitian adalah seluruh siswa kelas XI MIA yang berasal dari salah satu SMA di Lampung Selatan. Sampel penelitian diambil menggunakan teknik purposive sampling dan diperoleh kelas XI MIA 1 sebagai kelas eksperimen dan kelas XI MIA 4 sebagai kelas kontrol. Analisis data penelitian menggunakan uji perbedaan dua rata-rata yaitu uji $t$. Hasil penelitian menunjukkan bahwa rata-rata $n$-gain keterampilan berpikir tingkat tinggi yang diterapkan model pembelajaran POGIL lebih tinggi dari pada rata-rata $n$-gain keterampilan berpikir tingkat tinggi dengan model pembelajaran konvensional. Terdapat perbedaan $n$-gain HOTS yang signifikan antara kelas eksperimen dan kelas kontrol. Dengan demikian, disimpulkan bahwa model pembelajaran POGIL efektif untuk meningkatkan keterampilan berpikir tingkat tinggi pada materi garam menghidrolisis.
\end{abstract}

Kata kunci : keterampilan berpikir tingkat tinggi, garam menghidrolisis, POGIL. 


\section{PENDAHULUAN}

Pembelajaran merupakan suatu proses interaksi yang terjadi antara guru, siswa, dan komponen belajar lainnya untuk mencapai suatu tujuan pembelajaran guna memperoleh informasi, mengingat informasi yang telah diperoleh, dan menggunakan suatu pengetahuan (Woolfolk, 2009; Hosnan, 2014). Interaksi yang diharapkan adalah guru membimbing siswa untuk mengkonstruksi suatu pengetahuan secara mandiri. Interaksi seperti itu membuat siswa lebih aktif dan dapat melatih keterampilan berpikir siswa.

Guru telah mengakui pentingnya pembelajaran yang terpusat pada siswa. Siswa akan belajar dengan sangat baik ketika mereka terlibat dalam aktivitas kelas (Lee, 2012). Jika interaksi antara guru, siswa, dan komponen belajar lainnya sesuai dengan yang diharapkan, maka pembelajaran yang dilakukan dapat menjadikan pendidikan berkualitas.

Pendidikan berkualitas yang dimaksudkan adalah pendidikan yang sesuai dengan tujuan pembelajaran nasional, yaitu pendidikan yang menekankan pada kemampuan siswa dalam mencari tahu dari berbagai sumber, merumuskan permasalahan, berpikir analitis dan kerjasama serta berkolaborasi dalam menyelesaikan suatu masalah (Tim Penyusun, 2013a). Pendidikan yang berkualitas tentu akan menghasilkan generasi bangsa yang berkualitas pula. Apabila suatu bangsa ingin maju, diperlukan suatu cara untuk memperoleh generasi bangsa yang berkualitas salah satunya dengan meningkatkan mutu pendidikan.
Peningkatan mutu pendidikan guna menjawab tantangan perubahan kehidupan global terus dilakukan oleh pemerintah. Tantangan pendidikan yang dihadapi adalah bagaimana pendidikan menghasilkan sumber daya manusia yang memiliki kompetensi dan keterampilan, sehingga mampu untuk bersaing (Tim Penyusun, 2013b). Keberhasilan dalam menghasilkan sumber daya manusia yang berkualitas akan didapat ketika siswa mampu untuk berpikir tingkat tinggi, dimana siswa tidak hanya mengingat, memahami, dan menerapkan suatu konsep saja, melainkan siswa dapat menganalisis, mengevaluasi, serta mencipta (Laily, 2013; Julianingsih, 2017).

Gunawan (2006) menyatakan bahwa berpikir tingkat tinggi adalah suatu proses berpikir yang dilakukan seseorang dan mengharuskan mereka untuk memanipulasi informasi dan ide-ide dengan cara tertentu yang memberikan pengertian dan implikasi baru kepada siswa. Dengan demikian, keterampilan berpikir tingkat tinggi akan terjadi ketika siswa mengaitkan antara informasi baru dengan informasi yang sudah tersimpan di dalam ingatannya dan menghubungkan atau menata ulang serta mengembangkan informasi tersebut untuk mencapai suatu tujuan ataupun menemukan suatu penyelesaian dari suatu permasalahan. Sementara Zaini (2015) mengatakan bahwa berpikir tingkat tinggi adalah keterampilan seseorang berpikir yang mengkombinasikan antara berpikir kritis dan berpikir kreatif. Berpikir tingkat tinggi adalah operasi kognitif 
yang banyak dibutuhkan pada proses-proses berpikir yang terjadi dalam memori jangka pendek (short-term memory).

Berdasarkan Taksonomi Bloom yang direvisi oleh Anderson dan Krathworl (2001), kemampuan menganalisis, mengevaluasi, dan mencipta yang termasuk dalam Higher Order Thinking Skill (HOTS) sangat dibutuhkan siswa untuk menghadapi masalah di dunia nyata (real life problem), karena masalah-masalah tersebut bersifat kompleks yang mengharuskan siswa dapat mencari solusi dalam memecahkan suatu permasalahan. Dengan melatih HOTS, siswa dapat menjadi pemikir yang mandiri, dapat memahami hal-hal kompleks yang menjadikan siswa terbiasa menghadapi permasalahan yang sulit, dan mampu mengaitkan informasi baru dengan informasi yang sudah tersimpan untuk menemukan suatu penyelesaian dari suatu keadaan yang sulit dipecahkan (Widodo dan Kadarwati, 2013; Hayon, Wariani dan Bria, 2017). Siswa yang dapat memecahkan suatu masalah, mampu mencari tahu informasi baru dan mengaitkan dengan informasi yang sudah tersimpan untuk menemukan suatu penyelesaian adalah siswa yang sudah melakukan inquiry learning.

Inkuiri merupakan salah satu pendekatan yang efektif untuk membantu siswa meningkatkan keterampilan berpikir dengan menggunakan proses mental yang lebih tinggi (Eggen dan Kauchack, 1996). Manzoor (2009) mengatakan bahwa, pengajaran dengan inkuiri menjadikan siswa dapat menemukan konsep dari hasil percobaan dan siswa dapat mengatasi kesulitan serta kendalakendala yang siswa hadapi selama melakukan suatu kegiatan percobaan. Pembelajaran dengan pendekatan inkuiri memungkinkan siswa lebih dinamis, mengikuti perkembangan zaman, serta melakukan sesuatu berdasarkan pembuktian (Sadeh, 2009). Pembelajaran seperti yang telah diuraikan di atas termasuk karakteristik model pembelajaran Process Oriented Guided Inquiry Learning (POGIL).

POGIL adalah salah satu pembelajaran yang mengembangkan inkuiri dan berorientasi pada proses. Pembelajaran POGIL merupakan pembelajaran yang berpusat pada siswa, siswa bekerja dalam kelompok dengan guru sebagai fasilitator (Moog dan Spencer, 2010). Melalui model pembelajaran POGIL, siswa dapat membangun pemahaman mereka sendiri dalam suatu proses yang melibatkan pengetahuan dan pengalaman yang telah didapatkan sebelumnya.

Ada lima tahapan pembelajaran POGIL menurut Hanson (2006), yaitu: (1) orientasi (orientation); eksplorasi (eksploration); pembentukan konsep (concept formation); (4) aplikasi (application) dan (5) penutup (closure). Tahap pertama yaitu tahap orientasi. Tahap orientasi adalah tahap membangun suasana pembelajaran yang responsif. Tahap ini mempersiapkan siswa untuk belajar, memberikan motivasi dan menciptakan rasa ingin tahu. Tahap kedua adalah tahap eksplorasi. Pada tahap ini siswa diberi serangkaian tugas untuk mewujudkan sesuatu yang 
seharusnya dipelajari dan mengarah pada pencapaian tujuan pembelajaran. Secara umum, ada tiga jenis pertanyaan yang digunakan dan masing-masing pertanyaan memiliki dengan tujuan yang berbeda. Tahap ketiga adalah tahap pembentukan konsep. Tahap pembentukan konsep merupakan proses membangun pemahaman konsep yang didapatkan dari pengalaman sebelumnya. Proses ini disusun dengan menyediakan pertanyaan agar siswa terdorong untuk berpikir kritis dan analitis karena mereka terlibat dalam eksplorasi. Tahap keempat adalah tahap aplikasi. Dalam tahap aplikasi siswa akan menggunakan istilah baru atau pola penalaran pada contoh lain. Tahap aplikasi diperlukan oleh siswa untuk mengenal pola dan memisahkannya dari konteks konkret dan/atau mengeneralisasikannya pada konteks yang lain. Tahap terakhir adalah tahap penutup. Pada tahap ini siswa akan diminta untuk mempresentasikan serta memberi kesimpulan terhadap hasil yang diperoleh dari kegiatan pembelajaran.

Model pembelajaran POGIL dapat diterapkan karena mampu melatihkan HOTS. Aktivitas dalam POGIL fokus pada konsep isi dan proses sains untuk mendorong pemahaman yang dalam terhadap materi serta mengembangkan kemampuan berpikir tingkat tinggi (Barthlow, 2011). Beberapa penelitian juga menyatakan bahwa POGIL dapat diterapkan untuk melatih HOTS, salah satunya adalah penelitian yang telah dilakukan oleh Irwanto, Saputro, Dwi, Rohaeti, Eli, dan Prodjosantoso (2018), dengan judul penelitian "Promoting Critical Thinking and Problem Solving Skills of Preservice Elementary Teachers through Process-Oriented
Guided Inquiry Learning (POGIL)", hasil penelitian menunjukkan bahwa model POGIL dapat digunakan untuk meningkatkan keterampilan berpikir tingkat tinggi siswa. Berdasarkan kajian teoritis dan empiris yang diuraikan, pembelajaran POGIL dapat digunakan untuk melatihkan keterampilan berpikir tingkat tinggi siswa.

Namun faktanya, hasil observasi dan wawancara yang dilakukan dengan salah satu guru mata pelajaran kimia kelas XI MIA SMA di Lampung Selatan menunjukkan bahwa pembelajaran kimia yang dilakukan masih menggunakan pembelajaran konvensional. Proses pembelajaran yang dilakukan, lebih dominan menerapkan satu metode saja yaitu metode ceramah, kegiatan praktikum yang seharusnya dilakukan pada materi tertentu seringkali hanya sedekar didemontrasikan, bahkan tak jarang tidak dilakukan praktikum sama sekali. Selain itu, lembar kerja siswa yang diberikan oleh guru hanya berupa rangkuman materi dan kumpulan soal-soal dengan ranah menghafal saja. Pembelajaran konvensional khusunya dilakukan pada materi garam menghidrolisis. Berdasarkan fakta tersebut, pembelajaran konvensional yang dilakukan di sekolah jelas tidak melatihkan HOTS siswa.

Beberapa hasil penelitian juga menunjukkan bahwa HOTS siswa masih rendah. Salah satunya adalah penelitian yang dilakukan oleh Kurniati, Harimukti, dan Jamil (2016), diperoleh hasil penelitian yang menyatakan bahwa tidak adanya siswa berkemampuan HOTS tinggi.

Salah satu kompetensi dasar (KD) dalam kurikulum 2013 kelas XI IPA 
pada mata pelajaran kimia semester genap adalah KD 3.12, yaitu menganalisis garam-garam yang mengalami hidrolisis dan $\mathrm{KD} 4.12$ yaitu, merancang, melakukan, dan menyimpulkan serta menyajikan hasil percobaan untuk menentukan jenis garam yang mengalami hidrolisis (Tim Penyusun, 2013c). KD tersebut merupakan salah satu KD yang harus dikuasai oleh siswa pada mata pelajaran kimia. Berdasarkan KD dan silabus dalam kurikulum 2013 pada materi garam menghidrolisis, siswa juga perlu diberi kegiatan praktikum untuk mencapai KD tersebut serta diharapkan siswa mampu untuk memecahkan masalah dan membangun suatu konsep. Oleh karena itu, dibutuhkan model pembelajaran yang dapat membuat siswa lebih aktif dalam pembelajaran dan memberi kesempatan kepada siswa untuk membangun suatu konsep secara mandiri.

Untuk mencapai KD tersebut dapat digunakan model pembelajaran POGIL. Adapun proses pembelajaran dengan tahapan POGIL akan dituangkan dalam lembar kerja siswa (LKS). Berdasarkan uraian di atas, maka artikel ini bertujuan untuk mendeskripsikan model pembelajaran POGIL untuk meningkatkan keterampilan berpikir tingkat tinggi pada materi garam menghidrolisis.

\section{METODE}

Metode yang digunakan dalam penelitian adalah quasi eksperimen dengan Pretest-Posttest Control Group Design (Fraenkel;Wallen;dan Hyun, 2012). Variabel bebas dalam penelitian ini adalah model pembelajaran. Model pembelajaran yang diterapkan adalah model pembelajaran POGIL dan model pembelajaran konvensional. Variabel terikat adalah keterampilan berpikir tingkat tinggi siswa. Adapun variabel kontrol adalah materi garam menghidrolisis dan guru.

Populasi dalam penelitian ini adalah seluruh siswa kelas XI MIA yang berasal dari salah satu SMA di Lampung Selatan Tahun Pelajaran 2018/2019 yang tersebar dalam 8 (delapan) kelas. Teknik pengambilan sampel dilakukan dengan teknik purposive sampling. Diambil 2 kelas untuk sampel penelitian, yaitu siswa kelas XI MIA 1 dan XI MIA 4 yang berjumlah 72 siswa. Masing-masing kelas terdiri dari 36 siswa. Kelas XI IPA 1 sebagai kelas eksperimen XI IPA 4 sebagai kelas kontrol.

Jenis data yang digunakan adalah data utama berupa hasil pretes dan postes keterampilan berpikir tingkat tinggi (HOTS) pada materi garam menghidrolisis di kelas eksperimen dan kelas kontrol. Data pendukung terdiri dari lembar aktivitas siswa dan lembar kinerja guru selama proses pembelajaran. Sumber data yaitu seluruh siswa kelas eksperimen dan kontrol.

Instrumen yang digunakan berupa soal pretes dan postes, lembar kerja siswa (LKS) dengan langkah model pembelajaran POGIL untuk materi garam menghidrolisis dan lembar kerja siswa (LKS) konvensional yang hanya berisi rangkuman materi dan latihan soal-soal serta rencana pelaksanaan pembelajaran (RPP). Instrumen yang digunakan dalam penelitian telah dilakukan uji validitas isi oleh dosen 
pembimbing menggunakan cara judgement.

Setelah diperoleh sampel penelitian, selanjutnya dilakukan pretes untuk mengetahui kemampuan awal berpikir siswa pada kedua sampel penelitian. Data skor pretes di kelas eksperimen dan kontrol yang diperoleh kemudian diubah menjadi nilai dengan menggunakan rumus:

$$
\text { Nilai pretes }=\frac{\sum \text { skor yang diperoleh }}{\sum \text { skor maksimum }} \times 100
$$

Data nilai pretes yang diperoleh, kemudian dihitung rata-ratanya. Untuk mengetahui kemampuan awal berpikir siswa, dilakukan uji kesamaan dua rata-rata terhadap rata-rata nilai pretes HOTS siswa. Sebelum dilakukan uji kesamaan dua rata-rata, terlebih dahulu dilakukan pengujian normalitas dan homogenitas menggunakan SPSS versi 23.0 sebagai uji prasyarat. Kriteria uji normalitas dan homogenitas adalah terima $\mathrm{H}_{0}$ jika sig. (2-tailed) $>0,05$ dengan taraf signifikan 5\% artinya sampel berasal dari populasi yang berdistribusi normal dan kedua kelas penelitian mempunyai varians yang homogen.

Sampel dalam penelitian berasal dari populasi yang berdistribusi normal dan memiliki varians yang homogen, sehingga uji kesamaan dua rata-rata yang digunakan yaitu, uji $t$. Kriteria uji $t$ adalah terima $\mathrm{H}_{0}$ apabila sig. $>0,05$, artinya rata-rata nilai pretes keterampilan berpikir tingkat tinggi siswa di kelas eksperimen sama dengan kelas kontrol.

Selanjutnya kedua kelas diberi perlakuan dengan menerapkan model pembelajaran yang berbeda. Kelas eksperimen diterapkan model pembelajaran POGIL dan model pembelajaran konvensional di kelas kontrol. Kemudian kedua kelas dilakukan postes. Data nilai pretes dan postes digunakan untuk menghitung $n$-gain keterampilan berpikir tingkat tinggi siswa, rumus n-gain adalah sebagai berikut:

$$
n \text {-gain }=\frac{\% \text { nilai postes }-\% \text { nilai pretes }}{\text { nilai maksimum }-\% \text { nilai pretes }}
$$

dengan kriteria $n$-gain:

"tinggi" jika $(<\mathrm{g}>)>0,7$;

"sedang" jika $0,3<(<\mathrm{g}>)<0,7$;

"rendah" jika $(<\mathrm{g}>)<0,3$.

Data n-gain yang diperoleh kemudian dihitung rata-ratanya, lalu digunakan untuk melakukan uji hipotesis. Pengujian hipotesis pada penelitian ini dilakukan setelah uji normalitas dan uji homogenitas terhadap rata-rata $n$-gain HOTS yang hasilnya adalah normal dan homogen, maka dilakukan pengujian hipotesis dengan uji perbedaan dua rata-rata menggunakan uji independent sample $T$ test dengan program SPSS versi 23.0 for windows.

Hipotesis $\mathrm{H}_{0}$ : Rata-rata n-gain HOTS siswa yang diterapkan model pembelajaran dengan menggunakan model pembelajaran POGIL lebih rendah atau sama dengan rata-rata $n$-gain HOTS siswa yang diterapkan pembelajaran konvensional. $\mathrm{H}_{1}$ : Rata-rata n-gain HOTS siswa yang diterapkan pembelajaran dengan menggunakan model pembelajaran POGIL lebih tinggi daripada rata-rata n-gain HOTS siswa dengan model pembelajaran konvensional. 


\section{HASIL DAN PEMBAHASAN}

Hasil penelitian diperoleh data berupa nilai pretes dan postes keterampilan berpikir tingkat tinggi yang kemudian dihitung rata-ratanya.

Rata-rata nilai pretes keterampilan berpikir tingkat tinggi (HOTS) dapat dilihat pada Gambar 1 sebagai berikut:

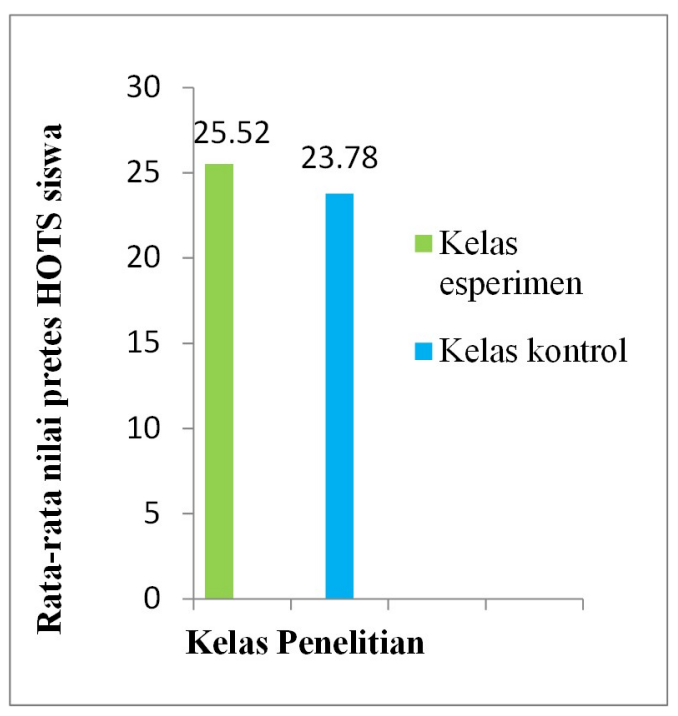

Gambar 1. Rata-rata nilai pretes HOTS.

Pada Gambar 1 menunjukkan bahwa keterampilan berpikir tingkat tinggi (HOTS) awal kedua kelas cenderung sama. Untuk mengetahui kesamaan secara signifikan, maka dilakukan uji kesamaan dua rata-rata dengan uji $t$.

Sebelum dilakukan uji $t$, terlebih dahulu dilakukan uji prasyarat yaitu uji normalitas dan homogenitas untuk mengetahui data berdistribusi normal dan memiliki varians yang homogen terhadap nilai pretes HOTS kelas kontrol maupun eksperimen. Hasil uji $t$ disajikan pada tabel berikut:
Tabel 1. Data normalitas rata-rata nilai Pretes HOTS.

\begin{tabular}{lcr}
\hline Kelas & Asymp. Sig. 2-tailed & Hasil \\
\hline Kontrol & 0,200 & Normal \\
& $(\mathrm{p}>0,05)$ & \\
Eksperimen & 0,134 & Normal \\
& $(\mathrm{p}>0,05)$ & \\
\hline
\end{tabular}

Berdasarkan Tabel 1, disimpulkan bahwa sampel penelitian dari kelas eksperimen dan kelas kontrol berasal dari populasi yang berdistribusi normal. Untuk hasil uji homogenitas rata-rata nilai pretes HOTS siswa diperoleh sig sebesar 0,379>0,05, sehingga data sampel terima $\mathrm{H}_{0}$ yang berarti kedua kelas penelitian mempunyai varians yang homogen. Karena data tersebut berdistribusi normal dan homogen, dilakukan uji kesamaan dua rata-rata menggunakan uji $t$.

Berdasarkan hasil uji kesamaan dua rata-rata menggunakan uji $t$ didapatkan sig.(2-tailed) adalah 0,562 $>0,05$, dengan demikian disimpulkan bahwa data sampel penelitian terima $\mathrm{H}_{0}$. Berdasarkan kesimpulan tersebut diketahui bahwa secara signifikan, kelas eksperimen dan kelas kontrol memiliki kemampuan kognitif yang sama.

Selanjutnya untuk rata-rata $n$-gain HOTS siswa dapat dilihat pada Gambar 2. Berdasarkan Gambar 2, terlihat bahwa rata-rata $n$-gain HOTS siswa di kelas eksperimen lebih tinggi daripada di kelas kontrol. Kelas eksperimen memiliki n-gain dengan kategori tinggi, sementara kelas kontrol memiliki n-gain dengan kategori sedang. 


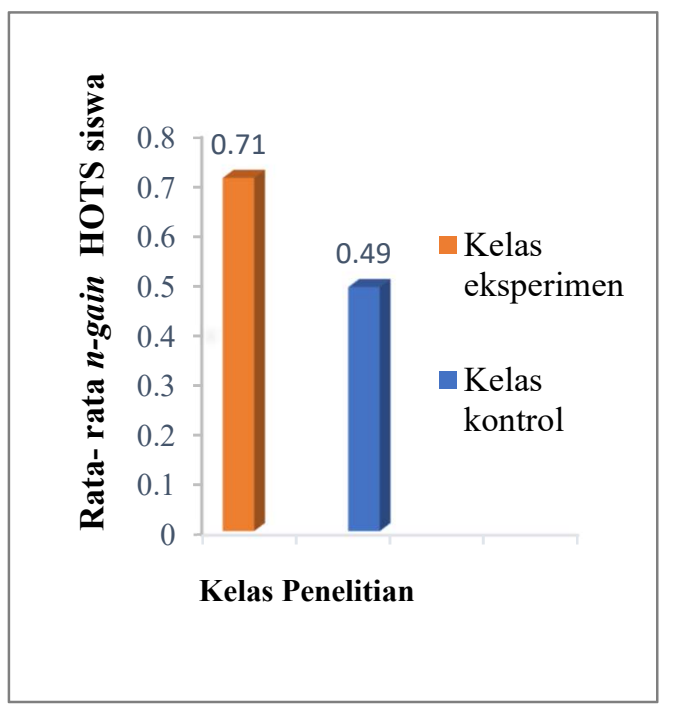

Gambar 2. Rata-rata n-gain HOTS.

Sebelum dilakukan uji perbedaan dua rata-rata terhadap rata-rata $n$-gain HOTS siswa, dilakukan terlebih dahulu uji normalitas dan uji homogenitas terhadap rata-rata $n$-gain HOTS siswa.

Tabel 2. Data normalitas n-gain HOTS

\begin{tabular}{lcr}
\hline Kelas & Asymp.Sig.2-tailed & Hasil \\
\hline Kontrol & 0,200 & Normal \\
& $(p>0,05)$ & \\
Eksperimen & 0,200 & Normal \\
& $(p>0,05)$ & \\
\hline
\end{tabular}

Berdasarkan Tabel 2 disimpulkan bahwa data $n$-gain kelas eksperimen dan kelas kontrol berasal dari populasi yang berdistribusi normal. Hasil uji homogenitas diperoleh sig. n-gain HOTS 0,098>0,05, sehingga dapat disimpulkan juga bahwa kedua kelas penelitian mempunyai varians yang homogen.

Kemudian dilakukan uji hipotesis berupa uji perbedaan dua rata-rata terhadap rata-rata n-gain HOTS menggunakan program SPSS versi 23.0 dengan uji independent sample T test. Hasil pengujian adalah sebagai berikut:

Tabel 3. Data uji perbedaan dua ratarata $n$-gain HOTS

\begin{tabular}{lrr}
\hline Kelas & Sig. & Hasil \\
\hline Eksperimen & 0,000 & Tolak $\mathrm{H}_{0}$ \\
Kontrol & 0,000 & Tolak $\mathrm{H}_{0}$ \\
\hline
\end{tabular}

Berdasarkan Tabel 3 diperoleh hasil sig. (2-tailed) $0,000<0,05$, sehingga data sampel tolak $\mathrm{H}_{0}$ dan terima $\mathrm{H}_{1}$. Artinya rata-rata $n$-gain HOTS siswa yang diterapkan model pembelajaran POGIL lebih tinggi daripada rata-rata $n$-gain HOTS siswa yang diterapkan model pembelajaran konvensional. Terdapat perbedaan n-gain yang signifikan antara kedua kelas. Dengan demikian dapat disimpulkan bahwa model pembelajaran POGIL efektif untuk meningkatkan HOTS siswa.

Model pembelajaran POGIL efektif meningkatkan keterampilan berpikir tingkat tinggi (HOTS). Hal ini sejalan dengan penelitian yang telah dilakukan Nurfitriyah (2017), hasil penelitian menunjukkan bahwa penggunaan model pembelajaran Process Oriented Guided Inquiry Learning (POGIL) pada materi larutan penyangga memiliki pengaruh yang positif untuk meningkatkan kemampuan berpikir tingkat tinggi siswa. Selain itu penelitian yang telah dilakukan Irwanto, Saputro, Rohaeti dan Prodjosantoso (2018) juga mendukung penelitian ini dengan hasil penelitian menunjukkan bahwa model pembelajaran POGIL dapat meningkatkan keterampilan berpikir tingkat tinggi siswa. Oleh karena itu, untuk menjelaskan kesimpulan dari penelitian ini, akan dikaji sesuai fakta 
yang terjadi pada tahapan-tahapan pembelajaran POGIL.

\section{Tahap 1. Orientasi (orientation)}

Pada tahap ini siswa diberikan suatu wacana yang disajikan pada lembar kerja siswa (LKS). Kemudian Siswa akan diminta untuk mengamati dan melakukan analisis terhadap wacana yang telah diberikan. Kemudian guru menanyakan tanggapan siswa terkait wacana.

Wacana pada LKS 1 berupa contoh garam menghidrolisis dalam kehidupan sehari-hari yang disertakan kegunaan dan sifatnya masing-masing. Setelah siswa mengamati dan melakukan analisis terhadap wacana, guru menanyakan tanggapan siswa dengan mengatakan "Bagaimana tanggapan kalian setelah membaca wacana tersebut? Adakah yang ingin kalian tanyakan?". Semua siswa masih terdiam dan belum ada yang bertanya. Pada tahap orientasi dalam kegiatan pembelajaran LKS 1, guru dapat menyimpulkan bahwa proses siswa mengamati dan menganalisis belum terfokus secara utuh pada wacana, sehingga guru memotivasi siswa agar siswa dapat menganalisis wacana yang diberikan sehingga rasa ingin tahu dapat diamati dari pertanyaan yang diberikan oleh siswa. Pada kegiatan pembelajaran LKS 1, pertanyaan yang muncul belum sesuai dengan yang diharapkan oleh guru.

Tahap orientasi pada LKS 2 masih berhubungan dengan tahap orientasi pada LKS 1. Sehingga yang ditanyakan oleh siswa masih berhubungan dengan pertanyaan pada kegiatan pembelajaran LKS 1. Bedanya adalah siswa terlihat lebih aktif karena mulai berani untuk bertanya.
Pada proses mengamati dan menganalisis wacana dalam LKS 3, sebelum guru mempersilahkan siswa bertanya, sudah ada beberapa siswa yang mengajukan pertanyaan. Pertanyaan-pertanyaan yang diajukan siswa misalnya "Bu, rumus apa yang dapat digunakan untuk menghitung $\mathrm{pH}$ larutan garam?", "Bu, apakah sama rumus yang digunakan untuk menghitung $\mathrm{pH}$ larutan garam dengan asam dan basa?", "Apa kegunaan garam $\mathrm{NH}_{4} \mathrm{Cl}$ ?", “Garam apa saja yang harga $\mathrm{pH}$ nya ditentukan berdasarkan pada besarnya harga Ka dan Kb?". Terlihat siswa sudah mulai berani untuk mengungkapkan apa yang mereka pikirkan melalui pertanyaan-pertanyaan yang disampaikan. Sudah cukup banyak siswa yang bertanya sesuai dengan yang diharapkan oleh guru.

Dalam pelaksanaan tahap orientasi model pembelajaran POGIL, guru sudah sesuai melaksanakannya baik pada kegiatan pembelajaran LKS 1, LKS 2 maupun LKS 3. Berdasarkan tahap orientasi yang dilakukan pada kegiatan LKS 1, LKS 2, dan LKS 3, terlihat bahwa aktivitas ingin tahu siswa semakin berkembang melalui meningkatnya jumlah siswa yang bertanya. Siswa menjadi lebih aktif dan berani dalam mengungkapkan apa yang mereka pikirkan. Tahap ini, mampu melatih keterampilan menganalisis. Sebab untuk menemukan masalah, siswa harus mampu menghubungkan, membedakan, dan mengorganisasikan apa yang ada pada wacana. Hal tersebut sesuai dengan pendapat Fadiawati \& Syamsuri (2016) yang mengatakan bahwa proses melatihkan keterampilan 
menganalisis siswa melibatkan proses kognitif yang meliputi membedakan, kemampuan mengorganisasikan, dan menghubungkan. Artinya siswa terlebih dahulu harus menemukan sesuatu yang menjadi inti permasalahan, kemudian siswa diarahkan pada kegiatan meninjau ulang permasalahan.

\section{Tahap 2. Eksplorasi (exploration)}

Tahap eksplorasi merupakan tahap kedua dari model pembelajaran POGIL. Pada tahap ini, siswa diberi serangkaian pertanyaan, data atau informasi untuk mengembangkan dan memahami konsep yang lebih dalam.

Kegiatan eksplorasi yang dilakukan pada pembelajaran LKS 1 memberikan kesempatan pada siswa untuk merancang sendiri percobaan yang akan dilakukan, yaitu percobaan mengidentifikasi sifat larutan garam. Sebelumnya semua siswa belum mengerti cara menentukan variabel percobaan. Banyak siswa yang pasif dan tidak mau bertanya, lalu guru terus membimbing dan meminta siswa untuk membandingkan dengan percobaan sebelumnya, yaitu percobaan larutan asam basa. Jawaban siswa menjadi cukup baik setelah mendapat arahan dari guru. Kekurangan pada jawaban siswa serta ketidaktepatan siswa dalam merancang disebabkan karena siswa tidak terbiasa untuk menentukan sendiri variabel percobaan, prosedur, alat dan bahan serta tabel hasil pengamatannya secara mandiri.

Biasanya siswa hanya mengikuti apa yang diarahkan oleh guru untuk melakukan langkah-langkah dalam percobaan. Sehingga keterampilan siswa dalam berpikir tidak dilatihkan, sebab yang dilakukan oleh guru membuat siswa menjadi tidak mengembangkan keterampilannya dalam berpikir. Kemudian ketika percobaan dilakukan, hanya sebagian kecil siswa yang aktif. yang ingin ditanya. Pada kegiatan ini, sikap kerjasama siswa terlihat kurang.

Pada pembelajaran LKS 2, siswa diberikan data hasil percobaan penentuan $\mathrm{pH}$ larutan garam. Siswa diminta melakukan analisis supaya memperoleh informasi yang memudahkan siswa mengembangkan konsep yang akan dibangun secara mandiri. Beberapa siswa mulai memahami dan langsung mengamati data yang disajikan. Sementara sebagian siswa lain kebingungan dan terlihat melamun. Kemudian guru perlahan membimbing siswa dalam menganalisis data yang disajikan.

Untuk kegiatan pembelajaran pada LKS 3, pada tahap eksplorasi siswa diberikan suatu data berupa persamaan reaksi berupa reaksi ionisasi garam, kesetimbangan ion garam dalam air, kemudian reaksi kesetimbangan basa/asam dan reaksi kesetimbangan air. Siswa diminta untuk mengamati reaksi. Pada tahap ini guru mengamati bahwa sebagian besar siswa aktif dalam mengamati data tersebut. Kegiatan tahap ini, memberikan kesempatan siswa untuk mengumpulkan informasi yang akan digunakan untuk membangun konsep pada materi garam menghidrolisis. Siswa juga berdiskusi dengan kelompok untuk bertukar pikiran. Kegiatan tersebut sesuai dengan Hanson (2006) yang menyatakan bahwa pada tahap eksplorasi siswa melakukan percobaan, 
kemudian mengumpulkan, memeriksa, dan menganalisis data atau informasi, menyelidiki hubungan, mengusulkan, mempertanyakan dan menguji hipotesis. Kegiatan pada tahap ini melatih keterampilan siswa dalam menganalisis dan mencipta. Aktivitas teliti, komunikatif, bertanya serta kerjasama dalam mempertimbangkan jawaban pun dilatihkan. Guru sudah sesuai dalam melaksanakan tahap eksplorasi ini.

\section{Tahap 3. Pembentukan Konsep (concept formation)}

Tahap pembentukan konsep ini merupakan tahap ketiga model pembelajaran POGIL. Pada tahap ini, siswa diminta untuk menghubungkan informasi yang sudah didapatkan dari tahap sebelumnya untuk membentuk suatu konsep pada materi garam menghidrolisis. Diberikan serangkaian pertanyaan yang akan membantu siswa dalam mengembangkan yang ada dan membangun konsep secara mandiri.

Pada LKS 1, pertanyaan yang diberikan untuk siswa akan membantu dalam membangun konsep materi garam menghidrolisis. Saat proses pembelajaran berlangsung, sebagian kecil siswa bertanya kepada guru dan siswa lain masih terlihat pasif. Pada saat ini guru kembali memberikan motivasi pada sisswa. Perlahan-lahan siswa mulai menjawab pertanyaan pada LKS dan guru membantu setiap langkahnya. Guru terus membimbing agar siswa dapat menghubungkan informasi yang telah didapat dengan pertanyaan yang ada. Pada tahap pembentukan konsep LKS 1, masih banyak siswa yang kurang berpartisipasi dalam menyelesaikan pertanyaan yang diberikan. Pada pembelajaran LKS 1 aktivitas kerjasama, komunikatif, dan teliti siswa belum dapat dikatakan baik.

Tahap pembentukan konsep pada kegiatan pembelajaran LKS 2, siswa sudah mulai terbiasa menghubungkan informasi yang sudah didapatkan dengan pertanyaan yang ada untuk memperoleh definisi garam tidak menghidrolisis, garam menghidrolisis sebagian, dan garam menghidrolisis total. Beberapa kali ada siswa yang bertanya dan meminta guru untuk menjelaskan, misalnya pertanyaan seperti " $\mathrm{Bu}$, maksudnya bandingkan $\mathrm{pH}$ $\mathrm{H}_{2} \mathrm{O}$ dengan $\mathrm{pH}$ larutan garam $\mathrm{NH}_{4} \mathrm{Cl}$ ini bagaimana bu?". Guru mengarahkan dengan selalu memotivasi kepada siswa dalam mengembangkan keterampilan berpikirnya, seperti mengatakan "Coba amati kembali tabel pada tahap eksplorasi. Perhatikan nilai $\mathrm{pH}$ pada zat yang ditanyakan? Bagaimana nilainya? Apakah ada perbedaan? Jika ada perbedaan, maka tulis perbedaan tersebut. Jika tidak berarti keduanya memilik $\mathrm{pH}$ yang bagaimana?". Guru berusaha untuk memberikan arahan kepada siswa untuk memudahkan mereka dalam menjawab pertanyaan yang ada pada tahap pembentukan konsep. Selama siswa berdiskusi, guru juga menghampiri setiap kelompok dan menanyakan kesulitan pada masingmasing kelompok.

Berdasarkan kegiatan LKS 2, aktivitas kerjasama dan komunikatif siswa mulai terlihat, siswa tidak segan untuk bertanya. Namun masih terdapat sebagian kecil siswa yang belum berpartisipasi aktif.

Pada LKS 3, pertanyaan yang ada pada tahap pembentukan konsep 
terbagi dalam tiga penggalan. Pertanyaan yang diberikan bertujuan untuk menentukan rumus $\mathrm{pH}$ agar harga $\mathrm{pH}$ larutan garam dapat diketahui. Penggalan satu berisi pertanyaan-pertanyaan yang akan mengarahkan siswa agar dapat mengembangkan rumus menghitung $\mathrm{pH}$ suatu larutan garam yang bersifat asam. Penggalan dua berisi pertanyaanpertanyaan yang akan mengarahkan siswa agar dapat mengembangkan rumus menghitung $\mathrm{pH}$ larutan garam yang bersifat basa.

Sementara pada penggalan tiga, pertanyaan-pertanyaan yang disajikan pada lembar kerja siswa (LKS) adalah pertanyaan yang mengarahkan siswa dalam mengembangkan sendiri rumus menghitung nilai $\mathrm{pH}$ untuk larutan garam yang sifatnya ditentukan oleh besarnya nilai $\mathrm{Ka} / \mathrm{Kb}$. Dalam kegiatan pembelajaran LKS 3, siswa sudah terbiasa untuk menghubungkan informasi yang didapatkan dengan pertanyaan yang diberikan. Hal ini dibuktikan dengan waktu menjawab pertanyaan yang relatif cepat. Siswa sudah mampu untuk mengembangkan informasi sendiri meskipun konsep ini berkaitan dengan rumus-rumus. Hal ini menjadi bukti bahwa siswa sudah terbiasa untuk bekerja secara mandiri dan keterampilannya dalam menganalisis serta mengevaluasi telah terlatih.

Proses siswa dalam membangun suatu konsep semakin lama semakin baik. Siswa menjadi mandiri dalam membangun suatu konsep. Hal ini sejalan dengan penelitian yang dilakukan oleh Narudin dan Syafaati (2018) yang menyatakan bahwa model pembelajaran POGIL yang diterapkan menekankan pada aktivitas siswa untuk menemukan sendiri pemecahan masalah tetapi tetap melalui bimbingan dan arahan dari guru akan berdampak positif pada pencapaian konsep yang sedang dipelajari. Dengan demikian, tahap pembentukan konsep dapat melatih keterampilan menganalisis.

\section{Tahap 4. Aplikasi (application)}

Tahap aplikasi merupakan tahap keempat dari model pembelajaran POGIL. Pada tahap ini, diberikan 2 butir soal pada setiap LKS yang berkaitan dengan konsep yang sudah mereka dapat. Adanya soal ini bertujuan untuk melatih pemahaman siswa terhadap konsep yang telah mereka dapatkan. Soal yang diberikan memiliki kriteria untuk melatihkan keterampilan berpikir tingkat tinggi siswa.

Pada tahap aplikasi LKS 1, siswa diminta untuk mengelompokkan beberapa garam yang disediakan pada gambar berdasarkan sifat disertai dengan alasan pengelompokkan tersebut. Kemudian soal berikutnya berupa identifikasi berbagai larutan garam kemudian memperkirakan harga $\mathrm{pH}$ nya, lalu siswa diminta untuk memilih garam yang bersifat basa disertai dengan penjelasannya. Pada tahap aplikasi di LKS 1 hampir semua siswa masih bingung untuk memberi jawaban. Banyak siswa terlihat tidak mampu menerapkan konsep untuk menyelesaikan permasalahan dalam soal.

Untuk tipe soal yang diberikan pada LKS 2 berupa pernyataan. Kemudian siswa membuktikan benar 
atau tidak pernyataan tersebut. Pada soal berikutnya siswa diberikan wacana lalu ditanyakan reaksi hidrolisis yang terjadi dan sifat larutan garamnya. Pada proses menjawab soal pada LKS 2 ini, siswa terlihat lebih aktif untuk bekerjasama dan komunikatif menyelesaikan soal. Setelah siswa selesai menjawab soal, guru mempersilahkan untuk siswa menuliskan jawaban kelompoknya di papan tulis. Soal yang diberikan pada LKS ini adalah soal dengan kriteria untuk melatihkan keterampilan menganalisis dan mengevaluasi.

Pada LKS 3, diberikan soal untuk menghitung dan mengurutkan $\mathrm{pH}$ larutan garam dari yang terkecil. Cukup banyak siswa yang bertanya dan hampir semua siswa mengalami kesulitan, sebab berkaitan dengan rumus. Dalam hal ini guru membantu siswa. Setelah mendapat bimbingan guru, perlahan siswa dapat menjawab soal yang diberikan. Setelah itu, guru kemudian mempersilahkan siswa menuliskan jawabannya pada papan tulis. Kemudian siswa dari kelompok lain mengoreksi jawaban tersebut dan memri tanggapan jika memiliki saran atau jawaban yang berbeda. Guru memberi tanggapan mengenai jawaban yang tepat.

Soal yang diberikan pada LKS 3 memiliki kriteria soal yang dapat melatihkan keterampilan dalam menganalisis. Guru sudah sesuai dalam melaksanakan kegiatan pada tahap aplikasi disetiap pertemuannya.

Berdasarkan yang telah diuraikan di atas, dapat dilihat bahwa keterampilan berpikir tingkat tinggi siswa mengalami peningkatan pada setiap pertemuan.

\section{Tahap 5. Penutup (closing)}

Tahap ini merupakan tahap akhir dalam model pembelajaran POGIL. Pada tahap ini, guru melakukan evaluasi terhadap apa yang telah dilakukan oleh siswa. Siswa diminta untuk mempresentasikan hasil kerja mereka di depan kelas dan siswa lain memberi tanggapan. Kemudian guru memberikan perbaikan dari kesimpulan yang disampaikan siswa.

Berdasarkan aktivitas yang telah dilakukan sesuai model pembelajaran POGIL, membuktikan bahwa model pembelajaran POGIL efektif untuk meningkatkan keterampilan berpikir tingkat tinggi siswa khususnya pada materi garam menghidrolisis. Hal ini sesuai dengan yang diungkapkan oleh Barthlow (2011), yang menyatakan bahwa aktivitas dalam POGIL fokus pada konsep isi dan proses sains untuk mendorong pemahaman yang dalam terhadap materi serta mampu mengembangkan kemampuan berpikir tingkat tinggi siswa. Dengan ini jelas bahwa model pembelajaran POGIL dapat meningkatkan HOTS siswa. Hal ini juga dibuktikan dengan adanya perbedaan n-gain yang signifikan antara kelas eksperimen dengan kelas kontrol.

\section{SIMPULAN}

Berdasarkan hasil penelitian dan pembahasan disimpulkan bahwa: (1) rata-rata n-gain HOTS siswa di kelas eksperimen lebih tinggi daripada rata-rata n-gain HOTS siswa di kelas kontrol; (2) Terdapat perbedaan n-gain yang signifikan antara kelas eksperimen dengan kelas kontrol; dan (3) model pembelajaran POGIL efektif untuk meningkatkan keterampilan 
berpikir tingkat tinggi siswa pada materi garam menghidrolisis.

\section{DAFTAR RUJUKAN}

Anderson, L.W., dan Krathwohl, D.R. 2001. A Taxonomy for Learning Teaching, and Assesing: $A$ Revision of Bloom's Taxonomy of Educational Objectives. New York: Addison Wesley Longman, In.

Brathlow, M. J. 2011. The Effektiveness of Process Oriented Guided Inquiry Learning to Reduce Alternate Conceptions in Secondary Chemistry. (Disertasi). Liberty University: Tidak diterbitkan.

Eggen, P.D. and Kauchak. D.P. 1996. Learning and Teaching. 2 nd ed. Needdham Height, Massachussets: Allyn and Bacon.

Fadiawati, N dan Syamsuri, M. M. F. 2016. Merancang Pembelajaran Kimia di Sekolah. Yogyakarta: Media Akademi.

Fraenkel, J. R., Wallen N. E. dan Hyun, E. 2012. How to Design and Evaluate Research in Education. New York: McGraw-Hill Inc.

Gunawan, Adi W. 2006. Genius Learning Strategy. Jakarta: PT. Gramedia Pustaka Utama

Hanson, D. M. 2006. Designing Process-Oriented Guided Inquiry Activities. Faculty Guidebook: Stony Brook University.

Hayon, V. H. B., T. Wariani, dan C. Bria. 2017. Pengaruh Kemampuan Berpikir Tingkat Tinggi (Higher Order Thinking) Terhadap Hasil Belajar Kimia Materi Pokok Laju Reaksi Mahasiswa Semester I Program Studi Pendidikan Kimia
Unwira Kupang Tahun Akademik 2016/1017. Seminar Nasional Pendidikan Sain II UKSW. (309-316).

Hosnan. 2014. Pendekatan Saintifik dan Kontekstual dalam Pembelajaran Abad 21. Bogor: Ghalia Indonesia.

Irwanto, Saputro, Rohaeti, dan Prodjosantoso, A. K. 2018. Promoting Critical Thinking and Problem Solving Skills of Preservice Elementary Teachers through Process Oriented Guided Inquiry Learning (POGIL). International Journal of Instruction, 11(4).

Julianingsih, 2017. Pengembangan Instrumen Asesmen Higher Order Thinking Skill (HOTS) untuk Mengukur Dimensi Pengetahuan IPA Siswa di SMP. (Skripsi). Lampung: Universitas Lampung.

Kurniati, D., Harimukti, R., \& Jamil, N. A. 2016. Kemampuan Berpikir Tingkat Tinggi Siswa SMP di Kabupaten Jember dalam Menyelesaikan Soal Berstandar PISA. Jurnal Penelitian dan Evaluasi Pendidikan.

Laily, N.R. 2013. Analisis Soal Tipe Higher Order Thinking Skill (HOTS) dalam Soal UN Kimia SMA Rayon B Tahun 2012/2013. Jurnal Unswagati, 9(1).

Lee, K. 2012. Augmented Reality in Education and Training. Journal. Techtrends Link. Res.Pr Improve Learn, 56 (2). 13-21.

Manzoor, A.K. 2009. Teaching of heat and temperature by hypothetical inquiry approach: A sample of Inquiry teaching. Journal of Pysics Teacher Education. Online. 5 (2). 43-64. 
Moog, R. S. \& Spencer N. J. 2010. In Process Oriented Guided Inquiry Learning (POGIL). ACS Symposium Series. Washington DC: American Chemical Society.

Nurfitriyah, A. 2017. Pengaruh Penerapan Model Pembelajaran POGIL (Processs Oriented Guided Inquiry Learning) terhadap Hasil Belajar Kognitif dan Keterampilan Berpikir Tingkat Tinggi Siswa Kelas XI SMA Negeri 10 Malang pada Materi Larutan Penyangga. (Skripsi). Malang: Universitas Negeri Malang.

Sadeh, I dan Zion, M. 2009. "The Development of Dynamic Inquiry Performances within an Open Inquiry Setting: A Comparison to Guided Inquiry Setting”. Journal of research in science teaching. 46 (10). 1137-1160.

Tim Penyusun. 2013a. Peraturan Menteri Pendidikan Dan Kebudayaan Nomor 67 Tahun 2013 Tentang Kerangka Dasar Dan Struktur Kurikulum Sekolah Dasar/ Madrasah Ibtidaiyah. Jakarta: Kemendikbud 2013b. Peraturan
Menteri Pendidikan dan Kebudayaan Nomor 65 Tahun 2013 Tentang Standar Proses Pendidikan. Jakarta: Kemendikbud.

\begin{tabular}{l} 
2013c. Peraturan \\
\hline Menteri Pendidikan r dan \\
Kebudayaan Nomor 24 Tahun \\
2016 Tentang KI dan KD \\
SMA/MA. Jakarta: Kemendikbud.
\end{tabular}

Widodo dan Kadarwati. 2013. Higher Order Thinking Berbasis Pemecahan Masalah untuk Meningkatkan Hasil Belajar Berorientasi Pembentukan Karakter Siswa. Cakrawala Pendidikan. Th. XXXII, No. 1 (161-171).

Woolfolk, A. 2009. Educational Psychology : Active Learning Edition Edisi kesepuluh. Cetakan pertama. Yogyakarta: Pustaka Pelajar.

Zaini, M. 2015. Hasil Belajar dan Keterampilan Berpikir Tingkat Tinggi Siswa SMA pada Pembelajaran Biologi Menggunakan Model Pembelajaran Berdasarkan Masalah. Jurnal Pendidikan Biologi, 20(207) 